\title{
Pathogenicity of Aspergillus westerdijkiae to females and oothecae of Periplaneta americana
}

\author{
Patogenicidade de isolado de Aspergillus westerdijkiae \\ a fêmeas e ootecas de Periplaneta americana
}

\begin{abstract}
Mariah Valente Baggio $^{\mathrm{I}^{*}}$ Marcelo da Costa Ferreira ${ }^{\mathrm{I}}$ Antonio Carlos Monteiro Walter Maldonado Junior II Manoel Victor Franco Lemos ${ }^{\text {III }}$
\end{abstract}

\section{ABSTRACT}

Cockroach control is performed by the application of chemical insecticides which exert high selective pressure on populations and introduces synthetic substances in the environment, motivating the search for other methods of control such as entomopathogenic fungi. The objectives of this study were to investigate the pathogenicity of the JAB 42 Aspergillus westerdijkiae to females and oothecae of Periplaneta americana and to demonstrate its mechanism of action on oothecae. Suspensions containing $10^{6}$ to $10^{8}$ conidial $\mathrm{ml}$ were used to infect females and oothecae. Mortality and other variables such as scanning electron microscopy were used to demonstrate the mechanism of action of the fungus. The isolated JAB 42 A. westerdijkiae is pathogenic to oothecae of $\boldsymbol{P}$. americana, with low capacity to kill females. Adhesion, germination, penetration and extrusion of the fungus on the cockroach oothecae were observed.

Key words: cockroach, biological control, ovicide.

RESUMO

O controle de baratas realizado através da aplicação de inseticidas químicos exerce alta pressão seletiva sobre as populações e introduz substâncias sintéticas no ambiente, motivando a procura por outros métodos de controle, como os fungos entomopatogenicos. Os objetivos deste trabalho foram investigar a patogenicidade do isolado JAB 42 de Aspergillus westerdijkiae a fêmeas e ootecas de Periplaneta americana e demonstrar o mecanismo de ação sobre ootecas. Suspensões contendo $10^{6}$ a $10^{8}$ conídios $/ \mathrm{mL}$ do isolado foram usadas para infectar fêmeas e ootecas. A ação do fungo foi analisada pela mortalidade e outras variáveis, e por microscopia eletrônica de varredura. $O$ isolado $J A B 42$ de A. westerdijkiae é patogênico a ootecas de P. americana, tendo baixa capacidade de matar fêmeas. Foi observada a adesão, germinação, penetração e extrusão do fungo sobre ootecas da barata.

Palavras-chave: barata, controle biológico, ovicida.

\section{INTRODUCTION}

Treatment against household pests is an area of growing interest in the world and aims to control urban pests such as cockroaches (KASSIRI \& KAZEMI, 2012; MARICONI, 1999). The management of this insect is commonly performed only with the application of synthetic chemical insecticides. Less aggressive methods to the environment with low selective pressure on populations for tolerance or resistance have shown promising results, such as the entomopathogenic fungi Metarhizium anisopliae and Beauveria bassiana (HERNANEZ-RAMIREZ et al., 2008; HUBNER-CAMPOS et al., 2013).

There are reports that Aspergillus flavus is pathogenic to Blattella germanica (KULSHRESTHA \& PATHAK, 1997). $\boldsymbol{A}$. westerdjikiae was found in the parasitoid Prorops nasuta cuticle (VEGA et al., 2006). The present research isolated this fungus from $\boldsymbol{P}$. americana corpse, but there is no information on the pathogenic action of this microorganism to

'Núcleo de Estudo e Desenvolvimento em Tecnologia de Aplicação (NEDTA), Departamento de Fitossanidade, Faculdade de Ciências Agrárias e Veterinárias (FCAV), Universidade Estadual Paulista "Júlio de Mesquita Filho" (UNESP), 14884-900, Jaboticabal, SP, Brasil.

E-mail: mvalentebaggio@yahoo.com.br. ${ }^{*}$ Corresponding author.

IIDepartamento de Produção Vegetal, FCAV, UNESP, Jaboticabal, SP, Brasil.

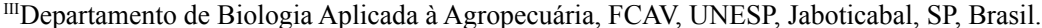


insects. $\boldsymbol{A}$. westerdijkiae produces ochratoxins, but it is not a common cause of food spoilage, and it is not considered a good indicator of mycotoxin production (WORLD HEALTH ORGANIZATION, 2008). Therefore, it would be interesting to evaluate the potential of this fungus in P. americana control.

Most of the studies target the postembryonic periods (HERNANEZ-RAMIREZ et al., 2008) of insects, but they should be essentially about spreading stages of the organism, such as females and eggs. P. americana can lay 51 oothecae in 25 months, generating about 816 descendants within two years (GALLO et al., 2002).

Little is known about the infection of oothecae by fungi, especially those of the genus Aspergillus, but the possibility of finding new pathogenic isolates to $\boldsymbol{P}$. americana oothecae can bring new perspectives of control, since no chemical insecticides are effective so far when applied topically on this phase of the pest. This study aimed to investigate the pathogenicity of the isolate JAB 42 of $\boldsymbol{A}$. westerdijkiae to females and oothecae of P. americana and to demonstrate its mechanism of action on oothecae, for use in biological control programs.

\section{MATERIAL AND METHODS}

Infection of $\boldsymbol{P}$ americana females and oothecae It was used the isolate JAB 42 of $\boldsymbol{A}$. westerdijkiae, identified by Dr. Stephen W. Peterson (Agricultural Research Service - US Department of Agriculture), obtained from a $\boldsymbol{P}$. americana adult, kept in the collection of Microbiology Laboratory of FCAV/UNESP. The oothecae and females of $\boldsymbol{P}$. americana were obtained from mass rearing of the laboratory NEDTA/FCAV/UNESP.

Treatments were: T1 - no application (control); T2 - solution of Tween $80^{\circledR}$ (polysorbate 80) $0.1 \%$ (vehicle of suspensions); T3 - suspension of $3 \times 10^{8}$ conidia $/ \mathrm{mL}$; T4 - suspension of $3 \times 10^{7} \mathrm{con}$./ $\mathrm{mL}$ and $\mathrm{T} 5$ - suspension of $3 \times 10^{6} \mathrm{con} . / \mathrm{mL}$.

Females were anesthetized with $\mathrm{CO}_{2}$ and $100 \mathrm{~mL}$ of suspensions were applied on their abdomens, using hand sprayer. Specimens were stored in plastic containers $(10 \mathrm{~cm} \times 10 \mathrm{~cm})$ with perforated lids for aeration at $27 \pm 0.5^{\circ} \mathrm{C}$ in the dark, $\mathrm{RH} \geq 80 \%$, and fed with water and dog food in abundance. Data were recorded for 20 days. Oothecae were cleaned with paper towel with deionized water and subjected to the same treatment and conditions as females. They were kept in Petri dishes containing moistened cotton and mortality was checked daily for 62 days.
Dead females and oothecae that did not show fungus extrusion were washed with sodium hypochlorite, dissected and its internal content introduced on PDA (potato dextrose agar) to confirm death caused by the fungus. The variables analyzed were: total mortality (TM), death confirmed by the fungus (DF), extrusion (EX) and mean death time caused by the fungus (TDF). The average time of fungal extrusion (TFE), total number of hatched nymphs per treatment (NN) and the average number of hatched nymphs per ootheca (NNO) were also evaluated.

The experimental design was completely randomized for females and in randomized blocks for oothecae, with a total of 250 individuals per experiment divided into five treatments and five replications. The analysis of variance was performed by $\mathrm{F}$ test and means were compared with Tukey test $(\mathrm{P} \leq 0.05)$. TM, EX and DF variables were transformed into arcsine $\sqrt{x / 100}$ and TDF/TFE was submitted to the Log-rank test, by Kaplan-Meier method using $\mathrm{JMP}^{\circledR}$ Pro 11.1.1 program. All variables satisfy the assumptions of homogeneity of variances and normality of the treatments.

Electron microscopy scanning of pathogenic action of isolate JAB 42 A. westerdijkiae in P. americana oothecae

Forty five $\boldsymbol{P}$. americana oothecae aged between 7 to 15 days were immersed for three minutes in suspension containing $6 \times 10^{8}$ con./ $\mathrm{mL}$ of the isolate JAB 42 of $\boldsymbol{A}$. westerdijkiae according to the protocol described by GARCIA et al. (2005). It was used the methodology of SANTOS \& MAIA (1997), described below, to conduct the electron micrographs.

The oothecae were chemically fixed with $3 \%$ glutaraldehyde in sodium phosphate buffer $0.1 \mathrm{M}$, $\mathrm{pH} 7.2$ to 7.4 , and placed in a refrigerator for $72 \mathrm{~h}$. The fixing process was performed during periods of $0 \mathrm{~h}, 1 \mathrm{~h}, 14 \mathrm{~h}, 18 \mathrm{~h}, 24 \mathrm{~h}, 48 \mathrm{~h}, 72 \mathrm{~h}, 96 \mathrm{~h}$ and $144 \mathrm{~h}$ after application of the fungal suspension. Five oothecae were used for each treatment.

The oothecae were washed six times with pure buffer solution every 15 minutes to be postfixed with osmium tetroxide $2 \%$ for at least $1 \mathrm{~h}$. Then, they were again washed with pure buffer and the samples were dehydrated with graded series of ethanol and subjected to drying with $\mathrm{CO}_{2}$ until the critical point. Finally, oothecae were covered with gold particles of $35 \mathrm{~nm}$ and electronically micrographed in the scanning electron microscope JEOL JSM 5410, operating at $15 \mathrm{kV}$. 


\section{RESULTS AND DISCUSSION}

Infection of $\boldsymbol{P}$. americana females and oothecae

Total mortality of $\boldsymbol{P}$. americana females sprayed with suspensions of $\boldsymbol{A}$. westerdijkiae isolate ranged between 14 and $32 \%$ and did not differ significantly from the control $(4 \%)$ and treatment with Tween $80^{\circledR}$ solution $(20 \%)$ (Table 1$)$. Although considered to be essentially a non-toxic adjuvant, Tween can cause the death of insects with differences in susceptibility of individuals of different species or within a population (OLIVEIRA et al., 2011).

In treatment $3\left(3 \times 10^{7}\right.$ con. $\left./ \mathrm{mL}\right)$ there was an average of $12 \%$ more dead females than in treatment T2 (Tween $80^{\circledR}$ ) (Table 1), suggesting that the fungus is able to infect and kill female $\boldsymbol{P}$. americana, regardless of the effect of Tween $80^{\circledR}$. The fungus took 8.7 days to cause the death of females, the average between the three treatment suspensions, and in $12 \%$ of adults of treatments 3,4 and 5 it was possible to verify its extrusion (Table 1).

It was observed that oothecae mortality rised due to the increase in the concentration of fungal suspension (Table 2). MNYONE et al. (2009) report a similar biological phenomenon with adults of Anopheles gambiae, in which mortality increased at interval concentrations of $10^{7}-10^{10}$ conidia/mL of $\boldsymbol{M}$. anisopliae and B. bassiana. These concentrations can be easily achieved in laboratory for further use in the control of insects on field trials.

The highest mortality caused by the fungus in this experiment was 58\% (T3) and differed from those in the controls (T1 and T2) and from a less concentrated suspension (T5) (Table 2). Mortality was found to be greater than $31 \%$ and $23 \%$ for oothecae treated with $2,5 \mu \mathrm{L}$ of $5 \times 10^{5}$ conidia of $\boldsymbol{M}$. anisopliae IP 46 and $M$. robertsii IP 34, respectively (HUBNER-CAMPOS et al., 2013).

In the mean time of 20.5 days it was possible to observe fungal extrusion on oothecae, particularly in the treatment concentration of $3 \times 10^{8}$ con./mL (Table 2). Oothecae with extruded fungus may be new pathogen inoculum sources.

In $14 \%, 12 \%$ and $2 \%$ of oothecae with fungus extrusion, which received treatments $\mathrm{T} 3$, T4 and T5, respectively, there was emergence of nymphs. This shows that the fungus is able to penetrate and infect the eggs but possibly without causing suffocation of the oothecae, as mentioned by HUBNER-CAMPOS et al. (2013).

There was no significant difference in the average number of nymphs per oothecae, but the application of $\boldsymbol{A}$. westerdijkiae at a concentration of $3 \times 10^{8}$ con. $/ \mathrm{mL}$ reduced by $48.20 \%$ and $35.15 \%$ the total number of nymphs when compared with the total number obtained in the T1 and T2 controls, respectively (Table 2). The reduction in the number of nymphs hatched has been observed for females of B. germanica treated with suspensions of $\boldsymbol{M}$. anisopliae (QUESADA-MORAGA et al., 2004).

The difference in susceptibility of females and oothecae to $\boldsymbol{A}$. westerdijkiae can be attributed to the life stage of the insect. Nymphs of B. germanica and P. americana oothecae were also reported to be less susceptible to the fungus M. anisopliae when compared to adults (LOPES \& ALVES, 2011; HUBNER-CAMPOS et al., 2013).

The infecting ability of Aspergillus can depend on intrinsic factors of the fungus, such as adhesion of conidia to the host (SHAHID et al., 2012) and the release of toxins (SHANKAR, 2013). There are also factors not related to the fungus that can influence infection process, such as the self-cleaning behavior of $\boldsymbol{P}$. americana

Table 1 - Total mortality (TM), death confirmed by the fungus (DF), extrusion (EX) and mean death time by the fungus (DTF) of $\boldsymbol{P}$. americana female sprayed with suspensions of different concentrations of the isolate JAB 42 of $\boldsymbol{A}$. westerdijkiae.

\begin{tabular}{lllll}
\hline Treatments & TM $(\%)^{1}$ & DF $(\%)^{1}$ & EX $(\%)^{1}$ & DTF $(\text { days })^{2}$ \\
\hline T1- Control & $4.0 \pm 2.2 \mathrm{a}$ & $0.0 \pm 0.0 \mathrm{a}$ & $0.0 \pm 0.0 \mathrm{a}$ & - \\
T2- Tween $80^{\circledR}$ at $0.1 \%$ & $20.0 \pm 6.3 \mathrm{a}$ & $0.0 \pm 0.0 \mathrm{a}$ & $0.0 \pm 0.0 \mathrm{a}$ & - \\
T3- $3 \times 10^{8} \mathrm{con} . \mathrm{mL}$ & $14.0 \pm 6.1 \mathrm{a}$ & $12.0 \pm 5.2 \mathrm{ab}$ & $12.0 \pm 5.2 \mathrm{a}$ & $9.0 \pm 3.7 \mathrm{a}$ \\
T4- $3 \times 10^{7} \mathrm{con} . \mathrm{mL}$ & $32.0 \pm 10.0 \mathrm{a}$ & $28.0 \pm 8.7 \mathrm{~b}$ & $12.0 \pm 3.3 \mathrm{a}$ & $10.9 \pm 1.6 \mathrm{a}$ \\
T5- $3 \times 10^{6} \mathrm{con} . \mathrm{mL}$ & $20.0 \pm 5.7 \mathrm{a}$ & $14.0 \pm 3.6 \mathrm{ab}$ & $12.0 \pm 3.3 \mathrm{a}$ & $6.3 \pm 2.0 \mathrm{a}$ \\
& $\mathrm{F}=2.124^{\mathrm{ns}}$ & $\mathrm{F}=7.692^{*}$ & $\mathrm{~F}=4.772^{*}$ & $\mathrm{X}^{2}=2.2212^{\mathrm{ns}}$ \\
CV $(\%)$ & 68.43 & 77.60 & 88.86 & \\
\hline
\end{tabular}

Means \pm standard error. Statistical analysis was conducted with data transformed into arcsine for TM, DF and EX. Means followed by the same letter in the column do not differ by ${ }^{1}$ Tukey tests $(\mathrm{P}=0.05)$ and ${ }^{2}$ log-Rank by comparing pairs of isolates by analysis of survival by Kaplan-Meier method. F - F test, $\mathrm{X}^{2}$ - Chi-square, ${ }^{*} \mathrm{~F}$ test significant at $5 \%$ of probability. ${ }^{\mathrm{ns}}$ not significant. CV: coefficient of variation. 
Table 2 - Total mortality (TM) death confirmed by the fungus (DF), extrusion (EX), average time of fungal extrusion (TFE), total number of hatched nymphs (NN) and average number of nymphs hatched per ootheca (NNO) of $\boldsymbol{P}$. americana oothecae sprayed with suspensions of different concentrations of the isolate JAB 42 of $\boldsymbol{A}$. westerdijkiae.

\begin{tabular}{|c|c|c|c|c|c|c|}
\hline Treatments & $\mathrm{TM}(\%)^{1}$ & DF $(\%)^{1}$ & $\operatorname{EX}(\%)^{1}$ & $\mathrm{TFE}^{2}$ & $\mathrm{NN}^{1}$ & $\mathrm{NNO}^{1}$ \\
\hline T1- Control & $6.0 \pm 2.2 \mathrm{c}$ & $0.0 \pm 0.0 \mathrm{c}$ & $0.0 \pm 0.0 \mathrm{c}$ & - & $137.4 \pm 3.7 \mathrm{a}$ & $14.6 \pm 0.1 \mathrm{a}$ \\
\hline T2- Tween $80^{\circledR}$ a $0.1 \%$ & $20.0 \pm 4.9 \mathrm{bc}$ & $0.0 \pm 0.0 \mathrm{c}$ & $0.0 \pm 0.0 \mathrm{c}$ & - & $109.8 \pm 6.1 \mathrm{ab}$ & $13.8 \pm 0.2 \mathrm{a}$ \\
\hline $\mathrm{T} 3-3 \times 10^{8}$ con. $/ \mathrm{mL}$ & $60.0 \pm 8.0 \mathrm{a}$ & $58.0 \pm 9.5 \mathrm{a}$ & $36.0 \pm 6.1 \mathrm{a}$ & $18.0 \pm 2.5 \mathrm{a}$ & $71.2 \pm 10.8 \mathrm{~b}$ & $13.5 \pm 0.6 \mathrm{a}$ \\
\hline $\mathrm{T} 4-3 \times 10^{7}$ con. $/ \mathrm{mL}$ & $46.0 \pm 4.6 \mathrm{ab}$ & $46.0 \pm 4.6 \mathrm{ab}$ & $26.0 \pm 4.6 \mathrm{ab}$ & $21.5 \pm 2.3 \mathrm{a}$ & $87.0 \pm 8.4 b$ & $13.6 \pm 0.2 \mathrm{a}$ \\
\hline \multirow[t]{2}{*}{ T5- $3 \times 10^{6}$ con. $/ \mathrm{mL}$} & $34.0 \pm 6.7 \mathrm{ab}$ & $28.0 \pm 7.7 \mathrm{~b}$ & $16.0 \pm 6.1 \mathrm{~b}$ & $22.0 \pm 6.3 \mathrm{a}$ & $95.2 \pm 11.0 \mathrm{~b}$ & $13.9 \pm 0.2 \mathrm{a}$ \\
\hline & $\mathrm{F}=12.84^{* *}$ & $\mathrm{~F}=34.15^{* *}$ & $\mathrm{~F}=20.48^{* *}$ & $\mathrm{X}^{2}=1.5728^{\mathrm{ns}}$ & $7.02^{* *}$ & $1.61^{\mathrm{ns}}$ \\
\hline LSD & 18.26 & 17.02 & 15.83 & & 40.05 & 1.41 \\
\hline $\mathrm{CV}(\%)$ & 29.08 & 36.41 & 47.92 & & 21.14 & 5.34 \\
\hline
\end{tabular}

Means \pm standard error. Statistical analysis was conducted with data transformed into arcsine $\sqrt{x / 100}$ for TM, DF and EX. Means followed by the same letter in the column do not differ by ${ }^{1}$ Tukey tests $(\mathrm{P}=0.05)$ and ${ }^{2}$ log-Rank by comparing pairs of isolates by analysis of survival by Kaplan-Meier method. F - F test, $\mathrm{X}^{2}$ - Chi-square, ${ }^{*} \mathrm{~F}$ test significant at $5 \%$ of probability. ${ }^{\mathrm{ns}}$ not significant. LSD: Least Significant Difference. $\mathrm{CV}$ : coefficient of variation.

females (SMITH \& VALENTINE, 1985), which can remove much of the conidia applied on their abdomens. This shows that oothecae can facilitate the pathogenic action of the fungus.

Few studies have been conducted aiming the control of oothecae (MOHAN, 1999; HUBNER-
CAMPOS etal., 2013). However, the use of fungi shows to be efficient against this phase of pest cycle. Given the result of this research it is important to consider the use of the isolate JAB 42 of $\boldsymbol{A}$. westerdijkiae in management of $\boldsymbol{P}$. americana oothecae.

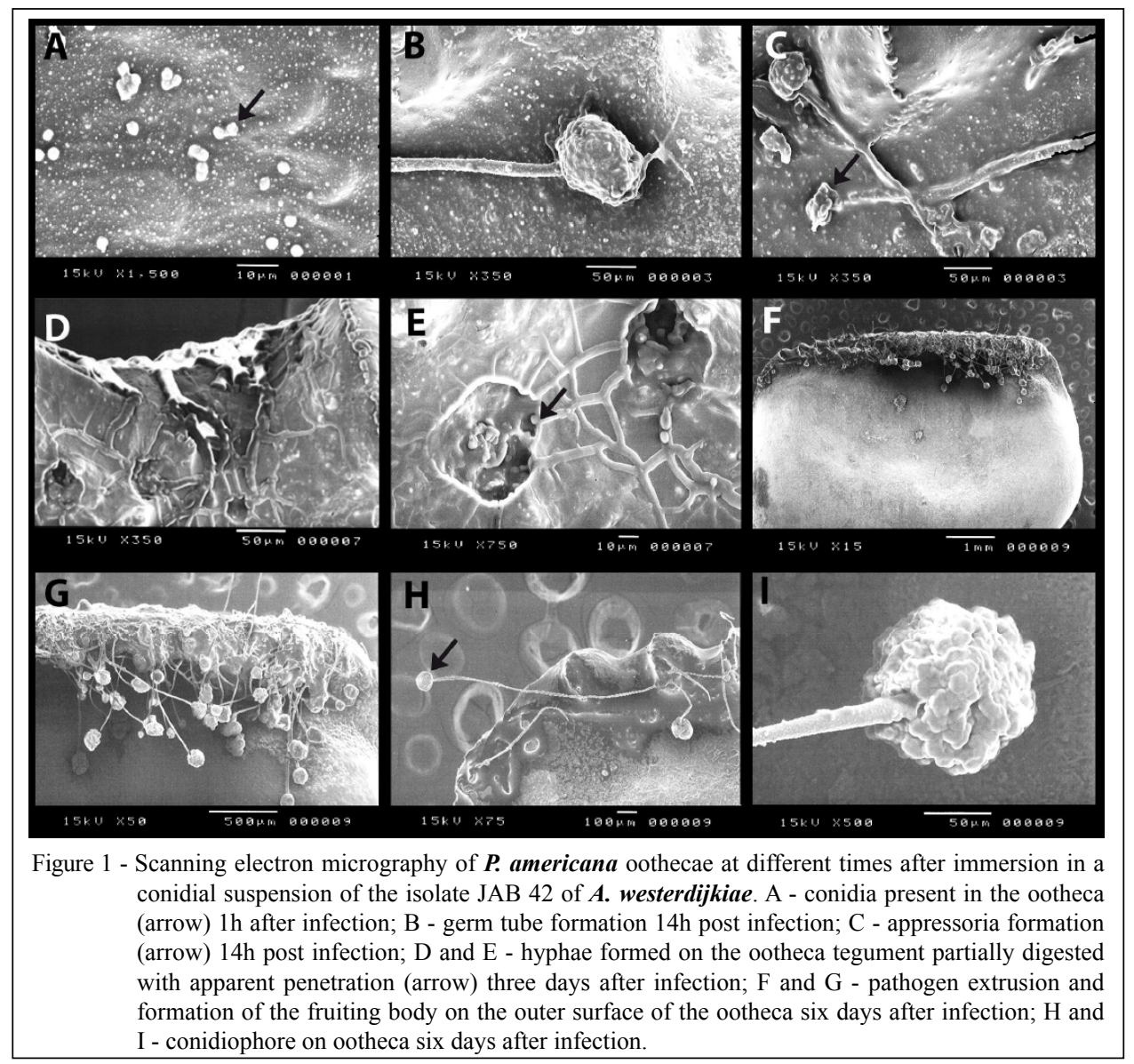

Ciência Rural, v.46, n.1, jan, 2016. 
Electron microscopy scanning of pathogenic action of isolate JAB 42 A. westerdijkiae in P. americana oothecae

The electron micrographs show germination, penetration and extrusion of $\boldsymbol{A}$. westerdijkiae in $\boldsymbol{P}$. americana oothecae (Figure 1). A similar result was found in a study on the infection of eggs of Rhipicephalus sanguineus by M. anisopliae (GARCIA et al., 2005). This shows that both fungi present the same process of infection.

The presence of conidia on the surface of ootheca was observed $1 \mathrm{~h}$ after immersion in the fungal suspension (Figure 1A). Thereafter it was observed the formation of the germ tube (Figure 1B) and appressoria fixing to the integument of ootheca (Figure 1C). After $14 \mathrm{~h}$ of immersion of oothecae, the penetration of the fungus process was initiated in the host.

The formation of hyphae and penetration into the ootheca occurred on the third day (Figures 1D and 1E) through holes present in the tegument of the ootheca. Such perforations may result from the action of enzymes secreted by the fungus, especially proteases, as ootheca is composed of $87 \%$ proteins (KRAMER et al., 1991). The fungus extruded on the sixth day (Figures $1 \mathrm{~F}$ and $1 \mathrm{G}$ ) with the presence of conidiophores (Figures $1 \mathrm{H}$ and 1I). Extrusion of $\boldsymbol{A}$. westerdjikiae occurred through the teeth in the upper side of the ootheca and the superior openings existing for air exchange (MAYA et al., 2000).

\section{CONCLUSION}

The isolate JAB 42 of $\boldsymbol{A}$. westerdijkiae is pathogenic to oothecae of $\boldsymbol{P}$. americana, with low capacity to kill females. The penetration occurs through the cuticle of the ootheca and the pathogenic action culminates with the fungus extrusion.

\section{ACKNOWLEDGEMENTS}

To Coordenação de Aperfeiçoamento de Pessoal de Nível Superior (CAPES) for Ph.D. Degree scholarship and to Fundação de Amparo a Pesquisa do Estado de São Paulo (FAPESP) for funding this work (Process nº 2012/14503-1).

\section{REFERENCES}

GALLO, D. et al. Entomologia Agrícola. Piracicaba: FEALQ; 2002.920p.

GARCIA, M. V. et al. Mechanism of infection and colonization of Rhipicephalus sanguineus eggs by Metarhizium anisopliae as revealed by scanning eletron microscopy and histopathology. Brazilian Journal of Microbiology, v. 36, n. 4, p. 368-37, 2005. Available from: $<$ http://www.scielo.br/scielo.php? script=sci_artte xt\&pid=S1517-83822005000400012>. Accessed: Sep. 02, 2014 doi: $10.1590 / \mathrm{S} 1517-83822005000400012$.
HERNANEZ-RAMIREZ, G. et al. Pathogenicity of Metarhizium anisopliae and Beauveria bassiana to the American cockroach (Dictyoptera: Blattidae). In: Proceedings of the 6th International Conference on Urban Pests; 2008; Hungary. Hungary: OOKPress Kft; 2008. p. 143-144.

HUBNER-CAMPOS, R. F. et al. Efficacy of entomopathogenic hypocrealean fungi against Periplaneta americana. Parasitology International, v. 62, n. 6, p. 517-521, 2013. Available from: $<$ http:// www.sciencedirect.com/science/article/pii/S1383576913001141>. Accessed: Sep. 02, 2014. doi: 10.1016/j.parint.2013.07.013.

KASSIRI, H.; KAZEMI, S. Cockroaches (Periplaneta americana (L.), Dictyoptera: Blattidae) as carriers of bacterial pathogens, Khorramshahr County, Iran. Jundishapur Journal of Microbiology, v. 5, n. 1, p. 320-322, 2012. Available from: <http://jjmicrobiol. com/?page $=$ article \&article_id $=2434>$. Accessed: Sep. 02, 2014. doi: 10.5812/kowsar.20083645.2434.

KRAMER, K. J. et al. Analysis of cockroach oothecae and exuviae by Solid-State ${ }^{13} \mathrm{C}$-NMR Spectroscopy. Insect Biochemistry, v. 21, n. 2, p. 149-156, 1991. Available from: <http://naldc.nal.usda. gov/download/11681/PDF>. Accessed: Sep. 02, 2014.

KULSHRESTHA, V; PATHAK, S. C. Aspergillosis in German cockroach Blattella germanica (L.) (Blattoidea: Blatellidae). Mycopathologia, v. 139, n. 2, p. 75-78, 1997. Available from: $<$ http://www.unboundmedicine.com/medline/citation/9549100/ Aspergillosis_in_German_cockroach_Blattella germanica_L_Blattoidea:_Blattellidae_>. Accessed: Sep. 02, 2014. doi: 10.1023/A:1006859620780.

LOPES, R. B.; ALVES, S. B. Differential susceptibility of adults and nymphs of Blattella germanica (L.) (Blattodea: Blattellidae) to infection by Metarhizium anisopliae and assessment of delivery strategies. Neotropical Entomology, v. 40, n. 3, p. 368-374, 2011. Available from: <http://www.scielo. br/scielo.php? pid $=$ S1519-566X2011000300010\&script $=$ sci arttext $>$. Accessed: Sep. 02, 2014. doi: 10.1590/S1519566X2011000300010.

MARICONI, F. A. M. As baratas. In: MARICONI, F. A. M. et al. Insetos e outros invasores de residências. Piracicaba: FEALQ, 1999. Cap. 1, p. 13-33.

MAYA, V. et al. Ultrastructural study of the crest in the ootheca of Periplaneta americana using a scanning electron microscope. Revista de Ecología Latinoamericana, v. 7, n. 1-2, p. 11-16, 2000. Available from: $<$ http://www.cires.org.ve/pdf/recol-v7n1a02.pdf $>$. Accessed: Sep. 02, 2014.

MNYONE, L. L. et al. Infection of the malaria mosquito, Anopheles gambiae, with two species of entomopathogenic fungi: effects of concentration, co-formulation, exposure time and persistence. Malaria Journal, v. 8, p. 309-321, 2009. Available from: <http:// www.malariajournal.com/content/8/1/309>. Accessed: Sep. 02, 2014. doi: 10.1186/1475-2875-8-309.

MOHAN, C. H. M. et al. Laboratory evaluation of the pathogenicity of three isolates of the entomopathogenic fungus Beauveria bassiana (Bals.) Vuillemin on the American cockroach (Periplaneta americana). Biocontrol Science and Technology, v. 9, n. 1, p. 29-33, 1999. Available from: <http://www.tandfonline. com/doi/abs/10.1080/09583159929884\#.VAX42vldX7w>. Accessed: Sep. 02, 2014. doi: 10.1080/09583159929884. 
OLIVEIRA, T. A. et al. Evaluation of the acute effects of organic solvents on adults of Sitophilus zeamais Motschulsky, 1855 (Coleoptera, Curculionidae). Journal of the Brazilian Society of Ecotoxicology, v. 6, n. 1, p. 9-13, 2011. Available from: <http:// siaiweb06.univali.br/seer/index.php/index/index $>$. Accessed: Sep. 02, 2014. doi: 10.5132/jbse.2011.01.002.

QUESADA-MORAGA, E. et al. Virulence, horizontal transmission, and sublethal reproductive effects of Metarhizium anisopliae (Anamorphic fungi) on the German cockroach (Blattodea: Blattellidae). Journal of Invertebrate Pathology, v. 87, n. 1, p. 5158, 2004. Available from: <http://www.sciencedirect.com/science/ article/pii/S0022201104001168>. Accessed: Sep. 02, 2014. doi: 10.1016/j.jip.2004.07.002.

SANTOS, J. M.; MAIA, A, S. A SEM improved technique for studying host-pathogen interaction of sedentary nematodes and for documentation of perineal pattern of Meloidogyne spp. Acta Microscópica, v. 6, p. 562-63, 1997.

SHAHID, A. A.; RAO, A. Q.; BAKHSH, A.; HUSNAIN, T. Entomopathogenic fungi as biological controllers: new insights into their virulence and pathogenicity. Archives of Biological Science, v. 64 , n. 1, p. 21- 42, 2012. Available from: <http://archonline.
bio.bg.ac.rs/VOL64/SVESKA1/04\%20-\%20Shahid\%20.pdf>. Accessed: Sep. 02, 2014. doi: 10.2298/ABS1201021S.

SHANKAR, J. An overview of toxins in Aspergillus associated with pathogenegis. International Journal of Life Sciences Biotechnology and Pharma Research, v. 2, n. 2, p. 16 - 31, 2013. Available from: <http://www.ijlbpr.com/ jlbpradmin/upload/ijlbpr_5183554255253.pdf>. Accessed: Sep. 02, 2014.

SMITH, B. J. B.; VALENTINE, B. D. Phylogenetic implications of grooming behavior in cockroaches (Insecta: Blattaria). Psyche, v. 92, n. 4, p. 369-385, 1985. Available from: <http://www.hindawi. com/journals/psyche/1985/081520/abs/>. Accessed: Sep. 02, 2014. doi: $10.1155 / 1985 / 81520$.

VEGA, F. E. et al. An insect parasitoid carrying na ochratoxin producing fungus. Naturwissenschaften, v. 93, n. 6, p. 297-299, 2006. Available from: <http://www.ncbi.nlm.nih.gov/pubmed/16555098>. Accessed: Nov. 04, 2014. doi: 10.1007/s00114-006-0101-6.

WORLD HEALTH ORGANIZATION. Evaluation of certain food additives and contaminants. Geneva: World Health Organization, 2008. v. 59. 471p. 